\title{
Issues, Challenges and Strengths of Sustainable Tourism Supply Chain After Covid-19 in Togean National Park-Sulawesi, Indonesia: A Preliminary Findings
}

\author{
Harifuddin Thahir ${ }^{1, *}$, Suryadi Hadi ${ }^{1}$, Femilia Zahra ${ }^{2}$, Irdinal Arif ${ }^{3}$ \\ Mohammad Ali Murad ${ }^{1}$, Mashur H. Lolo ${ }^{1}$
}

\begin{abstract}
${ }^{1}$ Department of Management, Faculty of Economics and Business, Tadulako University, Palu
${ }^{2}$ Department of Accounting, Faculty of Economics and Business, Tadulako University, Palu

${ }^{3}$ Department of Architecture, Faculty of Engineering, Tadulako University, Palu

*Corresponding author. Email: harifuddinthahir@untad.ac.id
\end{abstract}

\begin{abstract}
This study aims to determine the extent of the issues, challenges, and strengths of the tourism sector, which is a mainstay industry for almost every country in creating foreign exchange. However, since the implementation of social restrictions to deal with COVID-19, the tourism sector has been severely affected. The tourism industry is generally closed and tourist traffic is also closed. The process of closing access to tourist destinations has affected business activities in the upstream and downstream parts of the tourism supply chain management. This paper is prepared by taking a case study of tourism business in the Togean islands, Tojo Una-Una Regency, Central Sulawesi Province, Indonesia. Biodiversity, especially coral reef, flora and fauna around the island is also not inferior to the biodiversity in other tourist destinations in Indonesia. The analytical approach applied in this research uses qualitative analysis with a descriptive approach where the researcher is the key instrument. This descriptive method is carried out by describing the conditions that occur at the research location which is then carried out by drawing general conclusions from the data obtained. The problems faced by the tourism sector in this case are plastic waste, the use of fish anesthetics and fish bombs, licensing, labor standardization, access to telecommunications, electricity, and roads. The challenges faced are: labor standardization, marketing, coordination between sectors, environmental preservation. The strengths possessed by the tourism sector in the Togean Islands include: vocational education, community response, socio-culture, supporting infrastructure. The results of this paper can be used as input for policy makers in formulating sustainable tourism development strategies and become a reference for further research.
\end{abstract}

Keywords: Sustainable, Tourism, Supply Chain, COVID-19

\section{INTRODUCTION}

Foreign tourist activity is projected to increase from 1.5 billion in 2019 to 1.8 billion in 2030 [1]. However, the presence of COVID-19 has undermined the activity of this sector globally. Malaysia which implements Visit Malaysia 2020 must lose tourists, which are dominated by China and Singapore [2]. The same thing is experienced by Indonesia where the country's economy is experiencing the impact of the COVID-19 pandemic (McKibbin \& Fernando, 2020). Indonesia's lack of resources is the basis for reducing the impact of the economic recession caused by the COVID-19 pandemic
[3]. Companies that cannot survive the storm of recession are forced to lay off their employees and even lay off their employees to reduce even greater costs. As a result, 50 75 million workers involved in the tourism sector will lose their jobs due to the COVID-19 pandemic [4].

To maintain and continue the role of the tourism industry as a mainstay of foreign exchange, tourism businesses must prepare careful business plans in facing the sustainability of tourism after the COVID-19 pandemic. This paper is prepared to identify and determine the steps for the problems, challenges and strengths of tourism business actors, local governments, 
and other stakeholders by taking a case study of tourism businesses in the Togean Islands, Tojo Una-Una Regency, Central Sulawesi, Indonesia. The main reason is that these islands are one of the national strategic tourist destinations and are in demand by foreign tourists and have the potential to be developed as one of the favorite destinations for domestic and foreign tourists.

\section{SUSTAINABLE TOURISM SUPPLY CHAIN}

Several studies have proven that the implementation of sustainable tourism will have a positive impact on society, the environment and the economy [5]. Cultural preservation will occur because tourists want its preservation. The arrival of tourists will create services to support their activities so that job opportunities are more open and income distribution can take place. The environmental advantages possessed by a tourist destination will attract tourists to visit which has implications for increasing local community awareness of their environment. This results in a file increasing environmental awareness in society, as well as reevaluation of the natural environment through approval of conservation measures, protection and improvement of environmental quality $[6,7]$.

Tourists will be more attracted to countries or regions that pay attention to sustainable tourism [8]. Tourists who have a high awareness of sustainability will put forward the aspects of destination protection before deciding to visit $[9,10]$. The positive impact of sustainable tourism will be seen from the protection of natural, cultural resources and supporting facilities [11]. Based on sustainable supply chain management (SSCM) in tourism sector, accomodation is expected to be applied in TSSCM, while other sectors are having several barriers to apply TSSCM [12]. It can be seen that accomodation sector has opportunities to apply sustainable supply chain management.

Supply chain management in tourism sector is also complex. The interest of entities start from the upstream side to downstream side has differentiation. Managing each sector require collaboration among entities so that the operation might sustaian. Therefore, collaboration is the critical factor which would impact on tourism sustainability. Collaboration is the strongest causal attribute driving others in sustainable tourism, revealing that community well-being, guest cultures, information sharing, transparency and incentive alignment have shown the highest levels of driving power and dependence in the structure of the industry [13].

\section{METHODS}

This paper is prepared based on the results of research by taking a case study of sustainable tourism supply chain in the Togean Islands, Tojo Una-Una Regency, Central Sulawesi Province, Indonesia. The reason for choosing this tourist destination is because the location of this tourist area has previously been a favorite destination for foreign tourists, especially from Europe and is strategic for development. Biodiversity, especially coral reef, flora and fauna around the island is also not inferior to the biodiversity in other tourist destinations in Indonesia. The analytical approach applied in this research uses qualitative analysis with a descriptive approach where the researcher is the key instrument. This descriptive method is carried out by describing the conditions that occur at the research location which is then carried out by drawing general conclusions from the data obtained. This research was conducted to analyze and explore which are the barriers and drivers in the tourism sector. Researchers collected data through direct interviews using semi structured and observations to obtain material related to sustainable tourism supply chain in the Togean islands. Subjects interviewed included: business actors in the tourism sector, among others: transportation, accommodation, restaurants, government and other related parties.

\section{RESULTS AND DISCUSSIONS}

\subsection{Description of the Togean Islands}

Tojo Una-Una Regency have area of 5721.51 square kilometers consist of 12 subdistricts in 2019. Tojo Una Una region consists of 12 subdistricts that is divided into two categories, which 6 in mainland and 6 in islands. The Togean Islands are located in the middle of Tomini Bay, in a transverse position from west to east. To the south and west, separated from the deep ocean, the Togean islands are bordered by the mainland of Sulawesi island. Meanwhile, the Togean islands are bordered by the mainland of Sulawesi island, which is part of the Gorontalo province. The total land area of the Togean islands is approximately $755.4 \mathrm{~km} 2$ or about 75,000 ha. The spatial form of the Togean islands is a series of 7 main islands extending from west to east, namely the islands of Batudaka, Togean, Talatakoh, Una una, Malenge, Walea Kodi, and Walea Bahi. The islands are surrounded by several smaller islands, as well as dozens of uninhabited islets that are more like rocks sticking out of the sea. The Togean Islands have endemic fauna species [14], including Togean monkeys, Togean monkeys (Macaca togeanus), Togean monitor lizards (Veranus salvator togeanus), babirusa (Babyrousa babirussa), tangkasi (Tarsius sp), coconut crab (Birgus latro), cuscus (Phalanger ursinus), and deer (Cervus timorensis). In addition, the Togean Islands have hundreds of tree species. The waters of the Togean Islands also have all types of coral reefs in the world, including: fringing reefs, barrier reefs, patch reefs and atolls. Togean endemic reef, namely Acropora togeanensis. The recorded coral reef fish are 596 fish species belonging to 62 families, including Paracheilinus togeanensis and Ecsenius sp which are strongly suspected to be Togean endemic. In addition, 555 species of molluscs from 103 families, 336 types of Gastropods, 211 types of Bivalves, 2 types of Cephalopods, 2 types of Scaphopod and 4 types of Chiton were found [14]. 


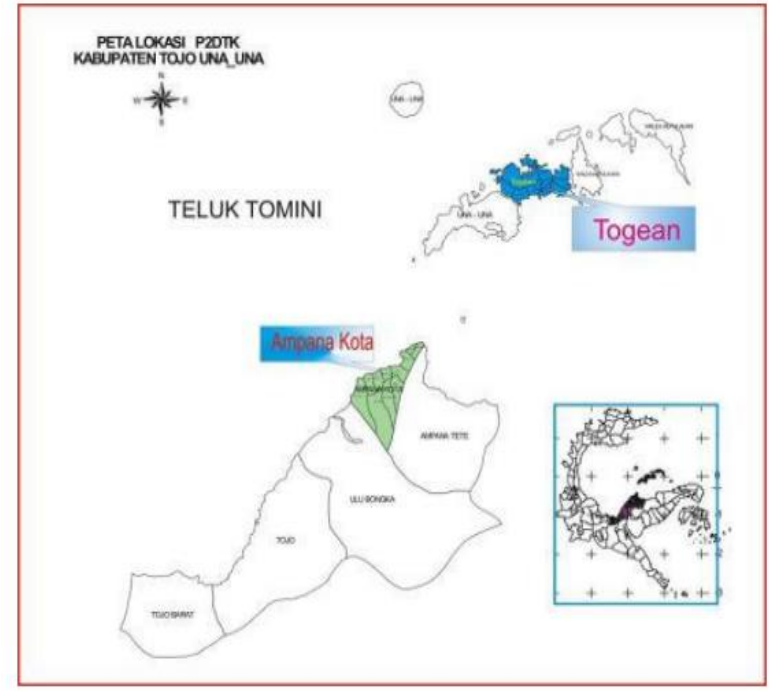

Source: Cultural and Tourism Office of Tojo Una-Una Regency

Figure 1. Togean Islands.

\subsection{Issues}

The results of observations and interviews conducted by researchers show that several tourism business managers in the Togean Islands have closed due to the COVID-19 outbreak. Only a small proportion of managers opened a business after the government issued a new normal policy. The main problems faced in implementing sustainable supply chain management. First, the increase in activities in the tourist destination area also affects the volume of plastic waste, both around the coast or in the waters near the Togean Islands. This plastic waste is very disturbing the habitat of fish and of government is easier than in the local government where the business is run. The negative impact of this pressure is the emergence of inconvenience from foreign business actors so that the possibility of them leaving their tourism businesses to be transferred to other countries.

Third, one of the main points in carrying out sustainable tourism is that business actors standardize business processes in accordance with the established code of ethics. The results of the survey conducted in the field showed that the implementation of standardization has not been implemented so this is still one of the problems in implementing sustainable tourism in the Togean Islands. Fourth, the communication network has actually been connected to several islands in the territory of the togean archipelago, but there are still several more islands that are still constrained by this problem. The facts obtained in the field show that several islands have received telephone and internet networks, for example in several villages including: Wakai, Dolong, Pulau Enam, and Pulau Papan. However, some favorite tourist spots still have difficulty getting telephone and internet networks. Fifth, electricity has been a major problem in the Togean islands for a long time. The government has made efforts to supply electricity but it is still limited to certain areas, for example in Wakai Village, which is the sub-district capital. At the time of this research, the electricity supply was provided by PLN from $6.00 \mathrm{pm}$ to $12.00 \mathrm{am}$. In some resort businesses, they work on their own electricity supply because the resort establishment is located on an island that is difficult to reach by PLN. Six, the problem of clean water has also become a major problem in the Togean Islands. Tourism business actors generally face difficulties in providing water supply. Some resorts are highly dependent on clean water

Table 1. Issue, Challenge and Strength of Sustainable Tourism Supply Chain

\begin{tabular}{|c|c|c|}
\hline Issues & Challenges & Strengths \\
\hline $\begin{array}{l}\text { - } \text { Environmental damage } \\
\text { - } \quad \text { Licensing } \\
\text { - } \quad \text { Standardization of business } \\
\text { - } \quad \text { Access to telecommunications } \\
\text { - } \quad \text { Electricity } \\
\text { - } \text { Clean Water } \\
\text { - } \quad \text { Roads }\end{array}$ & $\begin{array}{l}\text { - } \quad \text { Workforce Standardization } \\
\text { - } \quad \text { Certification } \\
\text { - } \text { and commitment } \\
\text { - Environmentally friendly } \\
\text { - } \text { Business certification } \\
\text { - Tourism Marketing }\end{array}$ & $\begin{array}{l}\text { - } \text { Vocational education } \\
\text { - } \quad \text { Community response } \\
\text { - } \quad \text { Supporting infrastructure } \\
\text { - } \quad \text { The advantages of tourist } \\
\text { - } \quad \text { destinations } \\
\text { Socio-cultural }\end{array}$ \\
\hline
\end{tabular}

other habitats in the sea so that efforts need to be made to reduce it. Catching fish by the community using anesthesia can disturb the coral reef habitat in these islands. If the liquid that becomes the anesthetic is spread, it will disturb the life of corals and other fish. A catching method that can endanger the survival of marine life is bombing it into the sea. This method is considered easy by fishermen to get fish, but this method can kill other small fish and coral reef habitats. Second, foreign business actors investing in tourist destinations still find it difficult to obtain permits that support tourism businesses. Sometimes the licensing process at the center supplies from other islands. This can increase the operational costs of tourism businesses because they have to use boats to carry water. Seven, road conditions in this area are still apprehensive and need high support from local and central governments. The inter-village connections on several islands still rely on sea transportation because the road conditions are still difficult to pass, especially during the rainy season.

\subsection{Challenges}

The implementation of sustainable tourism supply value management in the Togean Islands faces several 
challenges. First, the workforce involved in the tourism industry in the Togean Islands does not yet have sufficient standardization so this has an effect on service quality. Implementation of certification for workers in the tourism industry can help increase visitor satisfaction. Training on labor standardization should be improved so that awareness and motivation of the workforce in carrying out sustainable tourism can be properly maintained. Second, conflicts of interest with the managers of the Togean Islands National Park and the Tojo Una-Una Regency Tourism Office still frequently occur. Tourism development in the Togean Islands should always involve elements from the TNKT manager so that sustainable tourism goals and TNKT can be in line. Third, people in the Togean Islands do not have a high awareness of sustainable tourism. People still often dispose of their household waste in the sea, thus polluting marine life. Business management that does not yet have waste management also exacerbates this situation. Fourth, the procurement of business certification has not been optimized so that this will have an impact on service problems to tourists. Fifth, based on the collected visit data, the level of tourist visits is still very low in this area. Sustainable tourism marketing is very important to be carried out by business actors and local governments. Regional tourism marketing funds are still very low when compared to other regions that have previously marketed their tourism potential both domestically and abroad.

\subsection{Strengths}

This destination has in carrying out sustainable tourism supply chain management can be analyzed from several things. First, secondary school-level vocational education related to the tourism sector already exists in this area, namely in the capital city of Tojo Una-Una Regency, Ampana. The existence of this school can help provide employment opportunities and support the implementation of sustainable tourism in this region. Second, local people respond very positively to tourist visits to their area because they will get added value directly or indirectly. The community can provide services to deliver by boat to tourists to get around tourist destinations. Third, the airport which is located in mainland greatly supports tourism activities in this area but cannot yet be operated. The inter-island connection in this area is already better than in the previous condition. The government's commitment is very high to build a port on each island that connects economic and tourism activities. This is a strength of sustainable tourism development in this area because it can facilitate the flow of goods and people into and out of these islands. Fourth, this archipelago has a unique destination, namely Ubur-Ubur Lake which is rarely owned by other regions in Indonesia. Fifth, this area has a number of cultural uniqueness but has not yet been developed. The cultural uniqueness of the Bajoe Tribe in the Togean Islands also adds to the interest of visitors to see their socio-cultural life more closely. This great potential has not been developed optimally by the local government.

\section{CONCLUSION}

The tourism sector in the Togean Islands has to face several major problems in terms of environment, economy and socio-culture. Tourism businesses in this area face challenges that must be overcome so that negative impacts can be reduced and sustainable tourism goals can be achieved. The COVID-19 pandemic has an unfavorable impact on the tourism business sector, especially in the Togean Islands. The government closed transportation access for several months to reduce the spread of the virus, causing a number of tourism businesses to go bankrupt. Transporter or tourist transportation businesses feel the same way, many of whom have switched professions to become fishermen because no more tourists visit these islands.

The COVID-19 pandemic has a major impact on the entire tourism supply chain from upstream to downstream. However, when viewed from the perspective of future opportunities, this pandemic event can be used as a good momentum to coordinate with all stakeholders in implementing sustainable tourism supply chain management. The awareness of the importance of maintaining cleanliness from this virus can be applied by coordinating and collaborating between sectors and all tourism stakeholders so that the objectives of sustainable tourism supply chain management can be carried out with full awareness. The consensus between stakeholders can be a solid foundation in carrying out the standardization of sustainable tourism by all parties.

\section{ACKNOWLEDGMENTS}

The authors would like to express our appreciation to Tadulako University for funding this research under Tadulako University Research Grant (DANA DIPA Universitas Tadulako 2020).

\section{REFERENCES}

[1] UNWTO, "Annual report on Asia Tourism Trends," 2017.

[2] L. Foo, M. Cin, K. Tan and K. Phuah, "The impact of COVID-19 on tourism industry in Malysia," Current issue in Tourism, 2020.

[3] I. Riadil, "Tourism industry crisis and its impacts:Investigating the Indonesian tourism employees' perspective in the pandemic of COVID-19.," Jurnal Kepariwisataan Destinasi, Hospitalis, dan Perjalanan, 2020, pp. 1-15.

[4] UNWTO, "Impact assessment of the COVID-19 outbreak on international tourism," 2020.

[5] A. Abdallah and R. Al-Bakry, "Advancing towards sustainable economies: Examining resident attitudes and perceptions towards sustainable 
tourism development in Qatar," Vazardian, Croatia, Development and Entrepreneurship Agency (VADEA), 2019.

[6] P. Fullana and S. Ayuso, Tourismo Sostenible, Barcelona, Spain.: Rubes, 2002.

[7] J. Cardona, M. Aspelicueta Criado and A. Cantallops Sierra, "Proposal for general components of residents' attitudes: traditional society, development of tourism and evolution of attitude.," Revista Brasilera de Pesquisa em Turismo, 2015, pp. 240-257.

[8] J. Rivas Garcia and M. Diaz Magadan, "Los indicadores de sosteruiblidad en el turismo.," Rev.Econ.Soc.Tur.Medio Ambiente, 2007, pp. $27-$ 62 ,

[9] S. Conttrell, R. Duim, P. Ankersmid and L. Kelder, "Measuring sustainability of tourism in Manuel Antonio and Texel: A Tourist Perspective," Journal of Sustainable Tour, 2004, pp. 409-431.

[10] N. Ohtman, N. Anwar and L. Kian, "Sustainability analysis: Visitor's impact on Taman Negara," Journal of Tour Hospitality Culiner Arts, 2010, pp. 67-79.

[11] I. Pavic, A. Portolan and B. Puh, "(un) Supoorted current tourism development in UNESCO protected site: The case of old city of Dubrovnik," Economies, 2017.

[12] F. Xavier, T. Richard, S. Karen and K. Marianna, "Sustainable supply chain management in tourism," Business strategy and the environment Bus.Strat.Env., vol. 17, 2008, pp. 260-271.

[13] T. Ming-Lang, W. Kuo-Jui, L. Chia-Hao, L. Ming K, B. Tat-Dat and C. Chih-Cheng, "Assessing sustainable tourism in Vietnam: A hierarchical structure approach," Journal of Cleaner Production, 2018.

[14] G. Allen and S. McKenna, "A marine rapid assessment of the Togean and Banggai Island, Sulawesi Indonesia. Washington D.C. RAP Bulletin of Biological Assessment 20. Center for Applied Biodiversity Science, Conservation International," 2001.

[15] D. Santiago Escobar, "Turismo Sustenible y Desarrollo:Analisis del Desarrollo Turistico Sostenible Colombiano Mediante el Estudio de la Efectividad de Los Programas de Asistencia al Desarrollo Como Modelos de Ayuda a la Sostenibilidad Local," Universitat de Girona, 2018, pp. 1-345.

[16] W. McKibbin and R. Fernandom, "The economic impact of COVID-19.," 2020, p. 45. 